\title{
A ÉTICA PROTESTANTE E A IDEOLOGIA DO ATRASO BRASILEIRO
}

\section{Jessé Souza}

Max Weber é, sem sombra de dúvida, uma das referências fundamentais das ciências sociais no Brasil. Não só ele é um dos autores mais citados nas nossas dissertações e teses de mestrado e doutorado (Werneck Vianna, no prelo, p. 1), como, neste particular, juntamente com Marx, é a principal fonte de inspiração para a própria autocompreensão do Brasil. Apesar disto, muito embora tenhamos excelentes estudiosos da obra e de aspectos da obra weberiana, carecíamos de interpretações acerca desta influência. O trabalho de Luiz Werneck Vianna, "Weber e a interpretação do Brasil", ajuda a suprir esta lacuna importante. Com extraordinária riqueza analítica, este autor faz um interessante e convincente mapeamento da influência weberiana na interpretação do Brasil.

O esforço de Werneck Vianna me estimulou a tentar uma empreitada complementar à sua, ou seja, ao invés de uma análise imanente aos textos e aos autores, procurarei enfatizar os pressupostos teóricos destas análises. Como veremos adiante, esta literatura pressupõe a aceitação sem restrições do diagnóstico weberiano acerca do desenvolvimento ocidental. Assim, o que é atrasado ou avançado ou, em outras palavras, o que é tradicional ou moderno está implícito nestas análises como uma referência absoluta. O que é perdido neste processo é a real dimensão da noção de ambigüidade cultural. Esta noção, fundamental para qualquer ciência da cultura, percebe qualquer escolha cultural contingente como envolvendo simultaneamente perdas e danos. Nesta empreitada, procurarei me valer de ambigüidades da própria análise weberiana sobre $\mathrm{O}$ desenvolvimento peculiar do Ocidente.

Concordo com a tese de Werneck Vianna de que Weber foi usado para explicar o atraso da sociedade brasileira. O mesmo poderia ser dito, certamente, de Karl Marx. Nesse sentido, estes dois autores foram utilizados para ajudar a identificar os obstáculos que nos impedem de ser modernos. Dado o viés desenvolvimentista e modernizador das nossas ciências sociais, compreende-se a influência avassaladora destes autores clássicos entre nós. 
A partir de um interesse quase metateórico, gostaria de me concentrar nas noções mesmas de atrasado e moderno. É compreensível o uso de Max Weber neste contexto. As interpretações hodiernamente mais influentes de Max Weber, como as de Friedrich Tennbruck, Jürgen Habermas e Wolfgang Schluchter, enfatizam precisamente o aspecto evolucionista da sociologia weberiana. Para Habermas (1987, pp. 253-259), por exemplo, Weber teria, inclusive, antecipado o neo-evolucionismo contemporâneo. Ao contrário do evolucionismo clássico das ciências sociais do século XIX, como o marxista, por exemplo, Weber teria procurado evitar cuidadosamente a noção de etapas que se sucedem segundo uma ordem normativa necessária que parece inscrita na história.

No entanto, se Weber rejeita este evolucionismo material, ele seria adepto de um evolucionismo formal, como, por exemplo, o do próprio Habermas. Apesar da recusa à filosofia da história contida na noção de etapas necessárias de desenvolvimento, o evolucionismo formal acredita perfeitamente na existência de estágios de desenvolvimento com validade universal. Nos dois exemplos que citamos acima, Habermas e Weber, estes estágios de desenvolvimento hierarquizáveis e com pretensões de universalidade concentrar-se-iam no aspecto cognitivo e moral.

Isto explica, inclusive, por que os três comentadores de Max Weber acima citados tenham se dedicado, preferencialmente, ao estudo da sociologia da religião weberiana. É que tanto a moralidade quanto a necessidade de compreensão do mundo, para Weber, nascem como movimentos endógenos à racionalização religiosa. Daí que Weber, ao procurar as raízes da especificidade da cultura ocidental, tenha dado especial atenção ao estudo comparativo das grandes religiões mundiais. E qual seria a especificidade moral ocidental? E em que medida esta especificidade tem a ver com o que estamos chamando de ideologia do atraso brasileiro? Faço um apelo à paciência do leitor e sugiro que abordemos essas questões por partes. De início, vejamos o que significa para Max Weber a especificidade da cultura e da moralidade ocidentais.

\section{Weber e o Ocidente}

É certamente incorreto imaginar a importância da esfera religiosa para Max Weber como uma inversão da causalidade econômica marxista. A importância especial da esfera religiosa para Weber não é causal mas sim heurística. Sendo o fundador da sociologia compreensiva, que procura a interpretação das ações individuais a partir do sentido dado pelo agente, nada mais natural que a esfera social, onde ele identificou a gênese da produção de sentido social por excelência durante milênios, tenha tido a primazia do seu interesse genético e compreensivo.

Vamos procurar fazer uma leitura neo-evolucionista da sociologia religiosa weberiana, de modo a perceber onde Weber localiza a superioridade evolutiva ocidental nos campos moral e cognitivo. Este ponto será fundamental para que possamos compreender o que constitui a modernidade, em relação à qual nossa ideologia do atraso é contraposta. O neo-evolucionismo weberiano, como vimos, é formal e não material, ou seja, pretende-se universalidade apenas às estruturas de desenvolvimento; os conteúdos destas podem ser, ao contrário, particulares. As estruturas de desenvolvimento que nos interessam referem-se tanto às formas de consciência (moral e cognitiva) individuais, quanto às concepções de mundo societárias.

Temos aqui, portanto, a junção das perspectivas ontogenética (desenvolvimento individual) e filogenética (desenvolvimento societário ou da espécie). Este tipo de leitura pode ficar mais compreensível ao leitor contemporâneo se nos lembrarmos das suas afinidades com a psicologia do desenvolvimento cognitivo de um Piaget ou Kohlberg. Assim, a racionalização interna à esfera religiosa pode ser percebida como uma forma de resolver o dilema da interação do homem com o meio social e natural. Este processo de aprendizado pressupõe um aumento do grau de consciência e reflexividade acerca da realidade que nos cerca, assim como do grau de autonomia da consciência moral que nela atua. 
Ao falar da gênese das religiões, Weber esclarece que não pretende tratar da "essência" da religião, senão apenas indagar sobre as condições e efeitos deste tipo de ação comunitária. De acordo com o seu enfoque compreensivo, o ponto de partida são sempre as vivências e representações subjetivas dos indivíduos atores, ou seja, o "sentido" dado à ação pelos sujeitos (Weber, 1985, p. 245). Esse "sentido", pelo menos nas primeiras manifestações da religião e da magia, é dirigido a "este mundo" criado pela expectativa de que as coisas possam "ir bem e que se viva longos anos" (ibid). O elemento religioso ainda se encontra entranhado nos outros aspectos da vida cotidiana, especialmente o de natureza econômica. Esse é o reino do naturalismo préanimista, onde coisas e significados ainda não se separaram e o "sentido do mundo" como problema ainda não aparece. Apenas a maior ou menor cotidianidade dos entes é objeto da cognição mágica. O elemento apartado da familiaridade imediata do cotidiano é o que Weber chamará de "carisma" (idem, p. 247).

O naturalismo pré-animista baseia-se na crença de que criaturas determinam e influenciam o "comportamento" de coisas ou pessoas habitadas pelo carisma. Este é o núcleo da crença nos espíritos, em que espírito representa sempre algo indeterminado e material. A etapa seguinte, do ponto de vista lógico, é a imaginação de uma alma que propicia a transição do pré-animismo ao animismo em sentido estrito (Weber, 1985, p. 248). Na crença nas almas, que pressupõe já a prática dos magos, ocorre uma separação entre a idéia da entidade sobrenatural e os objetos concretos, os quais, agora, passam a ser apenas habitados ou possuídos.

O desenvolvimento cognitivo seguinte representa um salto qualitativo e implica a passagem do naturalismo para o simbolismo. O simbolismo pressupõe uma crescente abstração dos poderes sobrenaturais, dispensando, dessa forma, qualquer relação com objetos concretos. Decisiva para esse movimento em direção à impessoalidade da representação das forças sobrenaturais é a circunstância de que "agora não apenas as coisas e fenômenos que estão aí e acontecem representam um papel na vida, mas também coisas e fenômenos que significam algo e porque precisamente significam algo" (Weber, 1985, p. 248).
Como enfatiza Godfrey Lienhardt, o simbolismo propicia ao sujeito, pela primeira vez, uma forma de controle sobre o objeto da experiência através de um ato de conbecimento, levando a que se supere a relação naturalista do homem com o seu meio por força da autonomização do conceito em relação à coisa.

Um animal ou o homem pré-religioso podem apenas resistir passivamente à experiência do sofrimento e de outras limitações impostas pelas suas condições de existência. $\mathrm{O}$ homem religioso, ao contrário, pode, através de sua capacidade de simbolização, de certa forma "transcender e dominar", conseguindo, desse modo, uma liberdade em relação ao seu próprio meio impossível no passado. (apud Bellah, 1973, p. 274)

O aparecimento dos poderes sobrenaturais - almas, deuses e demônios - na sua relação com os homens possibilita a constituição da esfera ou do campo de ação religioso (Weber, 1985, p. 247). A relação das divindades com os homens é ainda, nessa fase de desenvolvimento, marcada pela ausência de distância. Distância essa que, no momento do ritual, desaparece completamente quando "o qualquer hora" transforma-se no "agora" (Bellah, 1973, p. 278). A ausência de distância indica a existência de uma mera "duplicação" entre o mundo das coisas e fenômenos e o mundo dos poderes sobrenaturais, denotando a existência de uma concepção de mundo monista (Schluchter, 1980, p. 15).

Essa circunstância leva a que a esfera religiosa não possua ainda nenhuma força propulsora capaz de canalizar a conduta prática em uma determinada direção. Mesmo assim, pode-se falar de uma "ética mágica" no sentido amplo do termo, como Weber (1985, p. 264) o faz, na medida em que, por força da imposição de tabus, produzse alguma forma de regulação das condutas. Essa primeira forma de positividade religiosa possui uma eficácia apenas estereotipadora (Weber, 1985, p. 249), no sentido de que serve, antes de tudo, à proteção de interesses extrareligiosos, faltando ainda a referência a um "mundo" especificamente religioso. 
Esse estado de coisas é decorrente do fato de o "desempenho" do simbolismo limitar-se ao mundo do ser; a distinção entre coisa e conceito, cuja importância já foi enfatizada, ainda não abrange a distinção entre ser e dever ser. Esse passo pressupõe, precisamente, uma concepção de mundo dualista, a qual só se desenvolverá com as religiões de salvação, e representa, em termos de lógica de desenvolvimento, um passo evolutivo decisivo em relação à concepção de mundo mágica. Ao invés de uma simples duplicação, temos aqui uma efetiva dualidade, na medida em que, ao contrário do mundo mágico, a esfera transcendental, especificamente religiosa, contrapõe-se à empírica reivindicando para si uma positividade e eficácia próprias. Mais ainda, a esfera transcendental passa a ser vista como a "mais importante", implicando a desvalorização da esfera empírica como o reino passageiro das criaturas (Weber, 1985, p. 319). A "verdadeira" realidade passa a ser a do "além", em oposição à empírica, a qual é vista, desde então, como passageira — nas religiões de salvação orientais — ou como o reino do pecado — nas religiões de salvação ocidentais.

$\mathrm{Na}$ introdução à ética econômica das religiões mundiais, Weber vincula esse processo de autonomização da esfera social religiosa com a transformação peculiar do sentimento impulsionador fundamental da ação religiosa, o qual passa a ser o sofrimento. No início do desenvolvimento da esfera religiosa o sofrimento era valorizado negativamente, como se pode observar pelo comportamento das comunidades arcaicas em festividades, ocasião em que os doentes e sofredores em geral eram tidos como legitimamente punidos pelos deuses e tornados objeto do ódio e desprezo geral, sendo impedidos de participar dos festejos. A religião servia, então, aos desejos dos poderosos e saudáveis de ver legitimada a própria felicidade (Weber, 1947, p. 242).

O caminho para a mudança radical dessa concepção começa com a distinção, relativamente tardia, entre a cura de almas, entendida como culto individual, e o culto coletivo, que cuidava apenas dos interesses mais gerais da comunidade. A cura de almas preocupa-se, ao contrário, com a questão da imputação causal da culpa do sofrimento individual, a qual foi assumida por dinastias de mistagogos ou profetas de uma divindade (Weber, 1947, p. 243). A partir dessa especialização, podem agora os sacerdotar vincular seus próprios interesses materiais e ideais aos motivos e necessidades da plebe.

Um passo seguinte consuma-se com a construção de mitos de salvação do sofrimento continuado, os quais permitem, pelo menos tendencialmente, uma interpretação racional do sofrimento. A matéria-prima original dessas construções eram os primitivos mitos da natureza que, a partir de sagas de heróis ou espíritos intimamente relacionados com fenômenos naturais, eram interpretados como cultos de salvação (Weber, 1947, p. 244). De uma maneira geral, foi formada a partir dessas esperanças de redenção uma "teodicéia do sofrimento", em evidente oposição às teodicéias da felicidade anteriores, que se baseavam, ainda, em fundamentos rituais e não éticos. Com o novo sentido do sofrimento, agora como sintoma de felicidade futura, abrem-se as portas para a conquista do imenso público de sofredores e oprimidos em geral (idem, p. 245).

Com a crescente compreensão da religião enquanto "teodicéia do sofrimento", inclinam-se os ricos e poderosos a abraçar outras fontes de legitimação da sua condição, como, por exemplo, o carisma do sangue. Os sofredores, ao contrário, saem em busca da idéia religiosamente motivada de uma "missão" confiada especialmente a eles (Weber, 1947, p. 248).

A teodicéia do sofrimento, como resultado da crescente racionalização das concepções de mundo religiosas, substitui, como uma metafísica tendencialmente racional, as concepções de mundo míticas, abrindo espaço, dessa forma, para o desenvolvimento de uma ética em sentido estrito. O pressuposto dessa passagem é um outro desenvolvimento cognitivo fundamental - como na transição do naturalismo ao simbolismo - que permite, agora, a distinção entre as esferas do ser e do dever ser. Como conseqüência temos uma mudança radical da relação dos homens consigo mesmo, com os outros e com seu ambiente. Deste momento em diante constitui-se um nova esfera moral; mais ainda, temos o aparecimento da moral enquanto tal, como esfera autônoma com uma positividade 
própria, na medida em que suas finalidades se separam de todas as outras finalidades mundanas.

Com a concepção de mundo dualista, por força da distinção entre o sagrado dever ser e o profano mundo do ser, constituem-se duas esferas concorrentes e paralelas, abrindo espaço para uma "rejeição religiosa do mundo", na medida em que o elemento empírico da realidade profana passa a ser desvalorizado pelo dever ser sagrado.

Uma primorosa análise das conseqüências e direções das rejeições religiosas do mundo é levada a cabo por Max Weber nas "Considerações intermediárias à ética econômica das religiões mundiais". $\underline{1}$ Todas as religiões de salvação, sejam elas ocidentais ou orientais, têm por base concepções de mundo dualistas. Embora, com certeza, com as conseqüências as mais distintas. 2 A diversidade dessas conseqüências e influências sobre a conduta prática confere, inclusive, o fio condutor de toda a sociologia da religião weberiana, assim como explica o peso heurístico da esfera religiosa para a explicação da especificidade cultural do Ocidente.

\section{A superioridade cultural e moral do} protestante

A especificidade do racionalismo ocidental, para Weber, resulta da forma peculiar segundo a qual a religiosidade ocidental soluciona o seu dualismo específico. O dualismo na sua versão ocidental é potencialmente tensional, ou seja, ao contrário do dualismo oriental, a ênfase é potencialmente mais ética do que ritualística. Neste sentido, abre-se a possibilidade do conflito aberto entre a positividade ético-religiosa e as demais esferas mundanas. É este o tema das "considerações intermediárias ao conjunto de estudos sobre sociologia das religiões". Se no catolicismo nós temos a ênfase numa estratégia de compromisso entre ética e mundo, no protestantismo ascético observamos uma continuidade e aprofundamento da ética judaica antiga, a qual enfatiza precisamente a tensão entre ética e mundo.

Max Weber se referia aos profetas éticos do judaísmo antigo como os primeiros homens que haviam logrado se libertar do "jardim mágico" onde toda a religiosidade primitiva se inseria. Havia a tentativa de conformar as esferas mundanas segundo os mandamentos da ética religiosa. Ao profeta Jeremias, por exemplo, não interessava compromissos. As lógicas mundanas deviam se conformar e se subordinar à mensagem religiosa. Para Weber, boa parte da extraordinária sobrevivência dos judeus como povo pária se deveu à eficácia do seu elemento ético.

No protestantismo ascético temos não apenas a clara noção da primazia da ética sobre o mundo, mas também a mitigação dos efeitos da dupla moral judaica (uma moral interna para os irmãos de crença e outra externa para os infiéis). A coerência e a disciplina da influência do comportamento prático pela mensagem religiosa pode, então, ser muito maior. O desafio aqui é o da ética que quer deixar de ser um ideal eventual e ocasional (que exige dos virtuosos religiosos quase sempre uma "fuga do mundo", como na prática monástica cristã medieval) para tornar-se efetivamente uma lei prática e cotidiana "dentro do mundo".

O que está em jogo em termos de desempenho cultural é uma primeira experiência histórica de moldar eticamente o mundo e, de forma conseqüente, transcender o dualismo religioso através da sua realização prática na sociedade.

Dentre as seitas do protestantismo ascético, foi o calvinismo quem liderou as grandes lutas culturais nos países capitalistas mais adiantados, conferindo também os estímulos mais conseqüentes para uma condução de vida ascética (Weber, 1979, p. 89). O dogma mais característico do calvinismo é a doutrina da predestinação (idem, p. 90). Segundo essa doutrina, apenas alguns homens são eleitos para a vida eterna, sem que se possa ter acesso aos motivos que levaram Deus a fazer tal escolha (idem, p. 92). Como Weber enfatiza, essa doutrina implica uma distinção radical 
tanto em relação ao catolicismo quanto em relação ao luteranismo, na medida em que os últimos não só defendem uma outra concepção da divindade, como também possuem uma concepção essencialmente distinta da piedade divina (idem, p. 103).

A doutrina calvinista da predestinação pressupõe uma concepção tal da divindade que, bem no sentido da divindade no Velho Testamento, implica um abismo intransponível entre Deus e os homens (Weber, 1979, p. 93), trazendo, como conseqüência, uma extrema intensificação da experiência humana da solidão. Uma outra conseqüência, talvez a mais importante, é a eliminação de toda mediação mágica ou sacramental na relação Deus/homens. Para Weber, essa última circunstância foi absolutamente decisiva para a superação do ethoscatólico e, em certa medida, também do luterano (idem, pp. 94-95), no sentido de que a ausência de mediação determina o fechamento dos espaços de "compromisso". O crente é deixado a si mesmo e apenas humildade e obediência em relação aos mandamentos da divindade podem decidir da sua salvação. A totalidade da condução da vida, como unidade, é o que conta para que se alcance a salvação, e não a soma de ações isoladas.

O patético isolamento individual cria, no entanto, uma sensação de insegurança insuportável para as necessidades emocionais de um homem normal. Para um virtuoso como Calvino não existia essa questão, posto que ele estava seguro da própria salvação. Para os seguidores, no entanto, a questão da dúvida da própria eleição ganha um significado central, propiciando a elaboração da doutrina da "certeza da salvação" (Bewärungsgedanke). Essa doutrina confere um significado sagrado ao trabalho intramundano ao interpretá-lo como meio para o aumento da glória de Deus na terra, de modo a dar ao crente a segurança de que seu comportamento é não apenas "agradável a Deus" (gottgewollt) mas, acima de tudo, "fruto direto da ação divina" (gottgewirket), possibilitando a fruição do bem maior dessa forma de religiosidade, qual seja, a certeza da salvação. $\underline{3}$

A noção de vocação ganha, assim, um novo sentido na medida em que passa a contar como "sinal da salvação"; mais ainda, como sinal da salvação a partir do desempenho diferencial. O objetivo da salvação e o caminho da salvação passam a exercer uma influência recíproca de tal modo que uma condução de vida metódica religiosamente determinada pode aparecer.

Com isso temos a superação não só da concepção tradicionalista de vocação em Lutero, mas também do próprioethos tradicionalista enquanto tal. No lugar da concepção da salvação segundo a acumulação de boas ações isoladas, temos agora a visão de que a vida tem de ser guiada a partir de um princípio único e superior a todos os outros: que a vida terrena deve valer apenas como um meio (e o homem, um mero instrumento de Deus) para o aumento da glória divina na terra. Todos os sentimentos e inclinações naturais deveriam subordinar-se a esse princípio, representando o protestantismo ascético, desse modo, uma gigantesca tentativa de racionalizar toda a condução da vida sob um único valor.

Ao contrário da ascese monástica medieval, que significa uma fuga do mundo, temos aqui uma ascese intramundana que direcionou toda a força psicológica dos prêmios religiosos para o estímulo do trabalho segundo os critérios de maior desempenho e eficiência possíveis. O elemento ascético age como inibidor da fruição dos frutos do trabalho, sendo o desempenho compreendido como atributo da graça divina e um fim em si.

No entanto, o espírito do capitalismo não apenas influi no mundo do trabalho ou na economia em sentido estrito, como também contribui de forma importante para a retificação da vida em geral.

Apenas o Ocidente consegue superar os limites de uma concepção de mundo tradicional e da forma de consciência que lhe corresponde. A aquisição de uma consciência moral pós-tradicional é o que está em jogo na passagem da ética da convicção, típica de sociedades tradicionais legitimadas religiosamente segundo uma moral substantiva, para a ética da responsabilidade, que pressupõe contexto secularizado e subjetivação da problemática moral. Esta passagem é "espontânea" apenas no Ocidente. O seu produto mais 
acabado é o indivíduo capaz de criticar a si mesmo e à sociedade onde vive. Este indivíduo liberto das amarras da tradição é o alfa e ômega de tudo que associamos com modernidade ocidental, como mercado capitalista, democracia, ciência experimental, filosofia, arte moderna etc.

Para Weber, toda a especificidade e, como iremos ver, toda a superioridadedo racionalismo ocidental perante os outros racionalismo culturais específicos decorre desta revolução de consciência protestante ascética. Os seus subprodutos morais e culturais são elogiados e invejados por Weber. Não nos esqueçamos do pendor político do homem Weber e do seu compromisso nacionalista e expansionista alemão.

Já em $A$ ética protestante e o espírito do capitalismo Weber identifica duas versões européias de protestantismo. Uma emotiva, grupal, que ele associa à Alemanha, e outra, racionalista e individualista, que ele associa à Inglaterra e aos Países Baixos. Sua aversão à primeira tradição e sua admiração pela última ficam claras em uma carta endereçada a Adolf Harnack no começo de 1906: "O fato de a nossa nação jamais ter sido formada na escola do protestantismo ascético é a fonte de tudo que eu odeio nela e em mim mesmo" (apud Roth, 1995, p. 85).

Esta impressionante confissão não é um dado isolado no contexto da obra weberiana. Bem ao contrário, ela é um resumo de toda uma concepção de mundo que está na base dos temas que comandaram a curiosidade de Max Weber. De início ela significa uma relativização da contribuição francesa para o racionalismo ocidental. A Revolução Francesa, apesar do alvoroço que provoca, não se compara a uma verdadeira revolução da consciência como a do protestantismo ascético. Instituições não se derrubam pela violência ou pelo sangue da vingança e do ressentimento. Uma real mudança institucional advém da conversão dos corações e mentes das pessoas. Isto tem a ver com o método compreensivo da sociologia weberiana, com o interesse histórico e genético de sua sociologia e com o potencial heurístico da racionalização religiosa já aludido acima.
Para Günther Roth, Weber era um whig que tratava o puritanismo como antecessor do liberalismo e individualismo moderno e que percebia o conteúdo político das lutas religiosas pela liberdade. Para Weber, o fundamento do individualismo moderno é que Deus deve ser mais obedecido do que os homens. Fundamento este que já é judaico, mas que o puritanismo leva ao limite. Este é o real elemento criativo da cultura ocidental. Esta pareceme ser também a razão da idealização weberiana das instituições políticas inglesas. No seu "Parlamento e governo em uma Alemanha reconstruída", de 1918 (Weber, 1958), onde procurava influenciar a gestação de novas instituições para a Alemanha do imediato pós-guerra, a sugestão é de que as instituições políticas britânicas, especialmente um parlamento livre e atuante, eram a base do poderio mundial britânico. Impressionava a Weber a conexão entre puritanismo, democracia, capitalismo competitivo e poderio mundial. Era isto que ele queria para a Alemanha de sua época.

Internamente, nos sentidos pessoal e político, Weber se interessava pelo componente voluntarista e radical do protestantismo ascético, que levava à conexão entre autocontrole e dominação do mundo exterior. Este componente era visto por ele como antídoto ao autoritarismo cultural e político alemão (Weber, 1958, p. 87). Se nós substituirmos a Inglaterra pelos Estados Unidos, vamos reencontrar esta preocupação na tradição weberiana do nosso pensamento social, que discutiremos a seguir.

Temos aqui, talvez, as causas da ambigüidade weberiana em relação ao lugar do racionalismo ocidental. Weber não se refere apenas à significação cultural deste racionalismo, mas também - o que acarreta conseqüências de larga escala — à exemplaridade do Ocidente protestante em relação às outras culturas mundiais. Como "filho" da moderna cultura ocidental, Weber procurou indagar, antes de tudo, como esta cultura específica se constituiu, o que fundamenta a sua peculiaridade em comparação com outras, e quais as direções para as quais ela aponta. É esta a origem do seu monumental estudo comparativo sobre as grandes religiões mundiais. A questão é determinar a especificidade do 
racionalismo ocidental. O fato é que Weber fica a meio caminho entre a opção de considerar este um racionalismo dentre outros de igual valor e de considerá-lo "superior" ao de outras culturas. Esta ambigüidade fica evidente já no primeiro parágrafo do prefácio geral aos estudos das grandes religiões mundiais (Weber, 1947, p. 1):

Problemas de história universal vão ser enfrentados por um filho da moderna cultura européia de forma correta e inevitável sob o seguinte ponto de vista: que associação de condições concorreram para que, precisamente no Ocidente, e apenas nele, tenhamos produções culturais, as quais - pelo menos assim gostamos de imaginar representam direções de desenvolvimento de significado e validade universais?

De início, é importante notar, significado e validade significam coisas distintas. Significado tem a ver com a noção de Heinrich Rickert de "significação cultural" (Kulturbedeutung), que designa um fenômeno digno de relevo, no sentido de importante como objeto de estudo, em comparação com outros mais discretos. O contexto, neste caso, é neutro com relação a valores, ou seja, não existe avaliação e sim simples "relação com valores", e a escolha se dá por razões heurísticas. Já validade remete a um outro estado de coisas. Validade implica avaliação e, portanto, defesa da exemplaridade da experiência ocidental em comparação com outras culturas. Uma leitura neoevolucionista da obra weberiana inspirada no evolucionismo formal de um Kohlberg ou Habermas, como a de Schluchter (1979, pp. 34-38), por exemplo, veria essa exemplaridade no campo moral. 4 Desta forma também, como exemplar e moralmente superior, creio eu, esta tradição foi assimilada pelo nosso pensamento social.

\section{O protestante e a nossa idelogia do atraso}

No final do século XIX, enquanto o Brasil dava os primeiros passos para a reformulação do arcabouço social herdado do período colonial, os Estados Unidos já se estavam tornando uma das maiores potências industriais do planeta. Se a sua influência política na arena internacional, em parte devido a uma persistente atitude isolacionista, só iria manisfestar-se mais tarde, com a administração de William McKinley no fim do século passado, e de forma mais conseqüente apenas com o fim da Primeira Guerra Mundial, o prestígio político das suas instituições democráticas já era um fato universal. Nossa primeira Constituição republicana já é um reflexo desta influência.

Não é difícil imaginar o que deve ter sido para toda uma geração de políticos e pensadores preocupados com as causas do atraso brasileiro o avassalador impacto dessa comparação tão pouco favorável a nós. Afinal, havíamos sido colonizados depois dos EUA, tínhamos uma dimensão continental semelhante (assim como uma fronteira interna e um padrão de povoamento igualmente comparáveis) e uma população que também crescia, com a maciça imigração européia, vertiginosamente. Por que somos nós tão pobres e atrasados e eles tão ricos e modernos? Esta pergunta se impunha quase que por si só.

A escolha dos Estados Unidos como nosso contraponto cultural por excelência não significa, gostaria que isto ficasse bem claro, uma simples oposição de projetos nacionais, à qual nós pudéssemos adicionar à vontade outras oposições, como em relação à França, à Alemanha ou outro país qualquer. Racionalismo para Weber é um conceito supranacional. Trata-se de um conceito abrangente que engloba peculiaridades das formações nacionais em favor da explicitação de traços mais básicos e heuristicamente mais significativos que fronteiras nacionais. Racionalismo é, portanto, um tipo-ideal. A escolha dos Estados Unidos, e não da França ou da Alemanha, deve-se ao fato de que a formação concreta da sociedade americana se aproxima, como nenhuma outra, $d a$ realização concreta do tipo abstrato de racionalismo ocidental no sentido weberiano. Daí seu enorme interesse para o mundo inteiro, e não apenas para nós. Os Estados Unidos são a nação por excelência do protestantismo ascético, onde este pode se desenvolver livre de outras influências, quase que como um tipo puro. 
Nas primeiras décadas deste século, quando uma geração de pensadores de extraordinário talento se dedicava a procurar interpretar o Brasil na sua especificidade cultural, a comparação implícita ou explícita com os EUA passou a ser uma preocupação central. Podemos, inclusive, perceber como a recepção de Max Weber por parte destes pensadores possibilita uma ruptura importante nos nossos estudos culturais, com a superação do paradigma racial antes predominante.

Sérgio Buarque de Holanda, tido, com toda a justiça, como um dos nossos maiores pensadores, é um caso típico do que afirmei. No seu Raízes do Brasil, nossa tradição cultural é contraposta à herança nórdica protestante. $O$ autor introduz um eixo temático que irá tornar-se dominante no nosso pensamento social a partir de então: a nossa mentalidade é avessa ao associativismo racional típico dos países protestantes, especialmente dos calvinistas (Buarque de Holanda, 1963, p. 11). Nossa tradição cultural seria "individualista amoral", incapaz de superar o imediatismo emocional que caracteriza as relações sociais dos grupos primários como a família. Como as instituições modernas mais importantes, como o Estado e o mercado, pressuporiam a superação do horizonte da solidariedade familiar, aí estariam as causas do nosso descompasso político e econômico. A falta de vinculo associativo horizontal, que possibilite as constelações de interesses de longo prazo, passa a ser percebida como a causa fundamental do nosso atraso social.

Este argumento é desenvolvido com maestria incomparável por Sérgio Buarque. As oposições entre trabalho e aventura, assim como entre o semeador e o ladrilhador, trabalhadas nos capítulos iniciais do livro, remetem todas àquelas características explicitadas acima que constituem a singularidade ética modelar e exemplar do Ocidente protestante: a precedência do interesse de longo prazo sobre os de curto prazo; a importância do controle racional dos afetos e as vantagens da cooperação social sobre o personalismo. Esta superioridade de "mentalidade social" é acrescentada e associada, no belo capítulo acerca do "homem cordial", central para toda a argumentação do livro, a uma teoria da personalidade. Nele se juntam concepção de mundo social e consciência individual num quadro de referência recíproca.

Apesar de este capítulo ser uma dessas raras manifestações de conjunção feliz de talento científico e literário, ele induz a erro vários comentadores de Sérgio Buarque. 5 É que, apesar de o tema do livro ser o confronto entre as tradições protestantes e católicas sincréticas como a nossa, a sua extensão à esfera da personalidade é feita de forma incompleta. Ao contrapor cordialidade à civilidade, o autor vincula esta última às "boas maneiras" e cita expressamente a tradição oriental como exemplo desta última tradição. Existe aqui, claramente, um descompasso entre a teorização acerca das concepções de mundo e aquela sobre a esfera da personalidade. É que a vinculação de boas maneiras à civilidade, sendo indiscutivelmente um traço cultural oriental, está na mais explícita oposição, e não em uma relação de complementaridade, como supõe Sérgio Buarque, à tradição cultural do associativismo e da solidariedade horizontal protestante.

No capítulo final do seu estudo sobre a "religião da China", Weber contrapõe os tipos de mentalidade e personalidade que ele julga serem os opostos absolutos do caminho protestante ascético ocidental. Seu escolhido é precisamente o confuciano oriental (tradição com enorme influência em todas as grandes culturas orientais), exatamente pela radical oposição entre uma civilidade - a qual creio que poderíamos entender como alguma forma de controle dos afetos pelo espírito, para usar as palavras de Sérgio Buarque - definida como boas maneiras e outra definida como dever ser ético. Segundo Weber, a primeira é realizada de "fora para dentro", ou seja, a partir de normas ritualizadas de comportamento induzidas socialmente. A segunda, bem ao contrário, advém de um impulso "de dentro para fora", a partir de um imperativo ético imposto à consciência individual. Existe entre as duas toda a distância que separa a ação ritualizada da ação ética. Apenas a última pressupõe internalização da regra moral que rege a conduta individual. Apenas a última pressupõe os ganhos cognitivos e morais peculiares à concepção de mundo e à personalidade ocidentais, conclui Max Weber. 
Assim, a oposição do homem cordial ao comportamento ritualizado do confuciano, do tipo social que une civilidade a boas maneiras, é certamente bem menor do que a distância que o separa do protestante ascético. Uma leitura atenta da caracterologia do homem cordial descobre que, ele sim, é, na verdade, o inverso perfeito do protestante ascético como definido por Max Weber. O homem cordial é a antipersonalidade por excelência, no sentido de que o contraponto implícito na cabeça de Sérgio Buarque, leitor de Weber de primeira hora, é a personalidade por excelência para Weber: o protestante ascético. $\underline{6}$ Apenas neste último a condução da vida é determinada "de dentro" (Weber, 1947, p. 534), por um ato de vontade que controla a emotividade em nome de uma ação conseqüente no mundo externo. Daí ser o racionalismo que habita este tipo de personalidade o da "dominação do mundo" (Rationalismus der Weltbeherrschung).

O homem cordial, nesta linha de raciocínio, ao contrário, assemelhar-se-ia, mais do que se contraporia, ao confuciano, definido por Weber como a oposição mais perfeita ao protestante asceta, dada a determinação externa e tradicional do seu comportamento. O racionalismo típico desta última forma de comportamento foi chamado por Weber, conseqüentemente, de "acomodação ao mundo" (Anpassung an die Welt). Tivesse Weber estudado o Brasil, no entanto, teria ele chegado, muito provavelmente, a uma conclusão semelhante à de Sérgio Buarque de Holanda, e eleito o "homem cordial" como o contrário perfeito do protestante nórdico. É que, como chama a atenção Sérgio Buarque, falta ao homem cordial até mesmo o dado ritualístico das boas maneiras que caracteriza o confuciano e o oriental em geral e que implica alguma forma, ainda que superficial e ditada pelo exterior, de regulação da conduta. Apenas o homem cordial é concebido como negatividade pura, entidade amorfa, dominada pelo conteúdo emotivo imediato e pela necessidade desmedida de reconhecimento alheio. Como resultado - daí a caracterologia do homem cordial ser a essência do livro —, não temos aqui nem mercado capitalista moderno nem democracia digna deste nome.
Isto não significa que o homem cordial, para Sérgio Buarque, não tenha qualidades. $O$ fato é que essas qualidades, que foram tão importantes na criação de uma grande nação nos trópicos, como a plasticidade, capacidade de acomodação e compromisso com o gentio e com o meio físico, são vistas agora como obstáculo para a criação de uma grande nação moderna. Este é o ponto. Para a construção da modernidade no Brasil, a herança ibérica passa a ser sinônimo de atraso e anacronismo por oposição à herança protestante nórdica. Em Sérgio Buarque, com certeza, temos um sentido agudo de algo que irá faltar a vários continuadores desta mesma tradição: a necessidade de se articular de algum modo nosso ser real com uma bem-vinda influência do modelo protestante idealizado. Este ponto é esboçado no famoso capítulo final de Raízes do Brasil, e é ainda melhor desenvolvido em textos posteriores do autor (Buarque de Holanda, 1978, pp. 23-66). Não existe em Sérgio Buarque, nem talvez seria razoável pedir isto à época da feitura do livro, uma consciência da ambigüidade constitutiva da herança protestante. Voltaremos a este ponto mais tarde.

Aproximadamente uma década depois teríamos Bandeirantes e pioneiros, de Vianna Moog. Esta análise penetrante do autor gaúcho toma explicitamente o mote da comparação direta com os EUA, o que é antes raro do que comum na nossa tradição culturalista. $\stackrel{7}{ }$ Moog expressa com clareza cristalina o que muitas vezes fica apenas implícito em várias produções do nosso pensamento social:

Como foi possível para os EUA, país mais novo do que o Brasil e menor em superfície continental contínua, realizar o progresso quase milagroso que realizaram e chegar aos nossos dias, à vanguarda das nações, com a prodigiosa realidade do presente, sob muitos aspectos a mais estupenda e prodigiosa realidade de todos os tempos, quando o nosso país, com mais de um século de antecedência histórica, ainda se apresenta, mesmo à luz de interpretações e profecias mais otimistas, apenas como o incerto país do futuro? (Moog, s/d., p. 15)

O atraso brasileiro é explicado tanto pelos fatores geográficos quanto por fatores ético-religiosos. Para Moog (s/d., p. 141), os EUA são o único país que nasceu 
calvinista. Daí decorre o orgulho de ser "americano" por oposição a europeu, no sentido do orgulho de quem está construindo a vida de acordo com uma idéia de comunidade tida como sagrada. Uma vida baseada na ética do trabalho, no aperfeiçoamento moral e no pragmatismo econômico. Este é o mundo do pioneiro americano para Moog. No Brasil, a figura correspondente, em termos de realidade histórica, é o "mazombo". O mazombo é o filho do português nascido no Brasil, cujas características são muito semelhantes ao perfil do homem cordial traçado por Sérgio Buarque: individualismo personalista, busca de prazeres imediatos, descaso por ideais comunitários e de longo prazo. Temos novamente, aqui também, o confronto do absolutamente positivo com o absolutamente negativo.

Apesar de este ser o tom do livro, ou seja, a contraposição de formas de colonização a partir de heranças religiosas e culturais distintas, uma levando a um desenvolvimento em progressão geométrica (o caso americano) e a outra conduzindo a uma mera progressão aritmética (o caso brasileiro), Moog percebe ambigüidades da tradição protestante, percepção esta rara entre nós. É que o autor percebe que a superioridade econômica protestante ascética não implica, obrigatoriamente, superioridade em todos os aspectos da vida. Moog observa, com muita sensibilidade, a incompatibilidade entre puritanismo e fraternidade, por exemplo, ligando-a à propaganda racista do imperialismo inglês e à discriminação racial aberta dos EUA. Voltaremos a este ponto mais tarde. Moog percebe não apenas a ambigüidade protestante em particular, mas também a ambigüidade capitalista em geral, antecipando alguns temas críticos da escola de Frankfurt, como a redução de todas as qualidades a uma lógica quantitativa. Este tema, creio eu, não perdeu em nada de sua atualidade. $\underline{8}$

Moog trabalha uma distinção temporal interessante quanto aos tipos sociais americanos que analisa. São duas as figuras representativas do espírito do nórdico americano para o autor: o pioneiro e o yankee. O pioneiro é o pequeno produtor rural, temporalmente anterior. É ele o povoador e conquistador de terras. O yankee, por sua vez, é o pioneiro já capitalista, empreendedor e urbano. A civilização yankee, para Moog, poderia ser resumida na seguinte frase de
Thomas Paine: "we have in our power to begin the world all over again" (nós temos o poder de refazer o mundo). E é dele a América de hoje.

No entanto, na esfera do símbolo, ainda é o pioneiro quem continua no imaginário americano como um mito, como fonte de inspiração, poesia e sonho. Como acontece sempre, ao converter-se em símbolo e afastar-se da realidade, a imagem do pioneiro torna-se resistente a esta última. A imagem do presidente Lincoln é apenas um dos exemplos desta transfiguração. Para Moog, o mesmo acontece com a imagem do bandeirante entre nós. No que diz respeito à realidade histórica, o bandeirante é o contrário do pioneiro: errante e de ânimo econômico predatório e extrativista. ${ }^{2} \mathrm{Na}$ esfera do símbolo, no entanto, ele representaria para nós o mesmo que a imagem transfigurada do pioneiro para os americanos.

São Paulo, o principal estado brasileiro em quase todos os aspectos, seria um exemplo perfeito, para Moog, desta transfiguração sem vínculos com a realidade. Se existe um quinhão do Brasil cujos méritos estão ligados ao espírito do pioneiro seria precisamente São Paulo. No entanto, peculiaridade da transfiguração simbólica, atribui-se ao bandeirante as realizações paulistas, conferindo-lhe qualidades que ele nunca teve. Este ponto é especialmente importante para nós, já que este tema de Moog é retomado mais tarde, segundo um registro muito particular.

Além desta vertente mais estritamente culturalista da influência weberiana entre nós, temos uma tradição que, sem descuidar dos estímulos socioculturais para o comportamento prático, prefere enfatizar o aspecto mais propriamente institucional da análise. Raimundo Faoro e Simon Schwartzman são bons exemplos desta tradição "institucionalista".

Faoro vai perceber a especificidade do atraso brasileiro a partir da herança portuguesa da transplantação de um aparato estatal patrimonialista, lá operante desde a Idade Média, para o Brasil. $\mathrm{Na}$ monarquia patrimonial portuguesa, o rei, senhor de toda a riqueza, seja ela territorial ou comercial, dirige a economia nacional como 
se fosse coisa sua, uma extensão da casa do soberano (Faoro, 1984, p. 20). Estas são as bases para o que Faoro chama de "capitalismo de Estado", que o Brasil herda de Portugal. A ambigüidade deste tipo de dominação patrimonial é que, se ela por um lado contribui para a estabilização e flexibilidade da economia, de modo a permitir uma notável expansão de um capitalismo de tipo comercial, por outro impede o lançamento das bases racionais do capitalismo industrial.

Para Faoro, a diferença entre as colonizações inglesa e portuguesa na América decorreria, portanto, da diversa constituição da instituição estatal em cada uma delas. Em Portugal teríamos o Estado patrimonial, estamental e centralizador. Na Inglaterra, ao contrário, um Estado que repele a centralização burocrática, refletindo mais o jogo dos interesses da sociedade. O primeiro propicia o esforço concentrado necessário às aventuras do capitalismo comercial, o segundo favorece a livre iniciativa dos interesses sociais que caracteriza o capitalismo industrial.

Simon Schwartzman é talvez o continuador mais eminente desta tradição institucionalista faoriana de inspiração weberiana. Para Schwartzman, o conceito weberiano de patrimonialismo não teria sido ainda devidamente aproveitado no seu potencial explicativo para o caso brasileiro. Uma noção bem compreendida do domínio patrimonial poderia possibilitar uma interpretação alternativa da passagem clássica do feudalismo ao capitalismo industrial na sua variante européia em geral e anglo-saxã em particular, de modo a explicar a singularidade do desenvolvimento brasileiro.

A "via dourada" do desenvolvimento capitalista pressupõe um estágio inicial tradicional, primitivo, que leva, mediante um processo de acumulação capitalista e posterior industrialização, a um estágio superior e mais moderno. Para Schwartzman (1975, p. 13), o caso brasileiro não se adequa a este modelo, não sendo nem tradicional ou primitivo, nem muito menos desenvolvido ou industrializado. $\mathrm{O}$ conceito weberiano de patrimonialismo seria fundamental precisamente para dar conta deste caminho específico, ibérico e brasileiro. As linhas gerais deste tipo de desenvolvimento obedecem ao esquema já traçado por Faoro. Não existe separação precisa entre as esferas econômica e política da sociedade e a busca do poder político não pode ser interpretada como decorrente de interesses autônomos e articulados. Ao contrário, a busca de poder político obedece à lógica do controle direto de uma fonte substancial de riqueza em si: o próprio aparelho estatal.

Enquanto, em Faoro, o estamento burocrático torna-se uma espécie de Leviatã social, coeso e sem fissuras, alfa e ômega de toda a estrutura social, Schwartzman procura descrever uma dualidade fundamental. Apesar de a realidade do domínio patrimonial ter sido o aspecto fundamental e dominante na nossa história, existe uma "outra" realidade que foge a este padrão e permite vislumbrar alternativas mais otimistas para nosso futuro.

Esta outra realidade, para Schwartzman, é possibilitada pelo aspecto peculiar do desenvolvimento de São Paulo. Para o autor, a diferença de nosso desenvolvimento histórico por comparação com o americano é que nos EUA o elemento tradicional (o Sul daquele país) foi dominado pelo elemento mais moderno e empreendedor (o Nordeste americano). No Brasil, para nossa infelicidade, teria acontecido o fato inverso: o Brasil tradicional, representado basicamente pelos eixos Nordeste, Minas e Rio de Janeiro, além do Rio Grande do Sul, teria sistematicamente vencido a influência mais moderna e empreendedora de São Paulo. Entre nós, ao contrário dos EUA, a tradição venceu a modernidade.

À primeira vista, o argumento do autor é bastante convincente e possui, decerto, um fundo de verdade. Nossa história é percebida como uma sucessão de empreendimentos econômicos de sucesso temporário, dada, entre outros fatores, a situação de dependência internacional. O Estado patrimonial se cria como um organismo fiscal e parasita destes centros econômicos dinâmicos. A monocultura do açúcar no Nordeste e a busca do ouro em Minas Gerais são os exemplos mais eloqüentes desta dinâmica social. A partir da decadência econômica destes empreendimentos, a elite local tende a substituir as "externalidades econômicas" por "externalidades políticas" 
(Schwartzman, 1975, p. 70), ou seja, tende a desenvolver um padrão dependente e incestuoso de relação com o Estado. A constituição do Estado patrimonial passa a ser o negócio.

A situação de São Paulo é distinta já por circunstâncias históricas de longo prazo. Para Schwartzman (1975, p. 49), "[...] desde o início da história do país, a antiga Capitania de São Vicente foi o primeiro núcleo de colonização que se moveu da costa para o interior, em total contradição com a política de expansão da Coroa portuguesa". Este padrão de colonização equivaleu a diferenças substanciais em relação à política da Coroa portuguesa. O quadro era de autonomia, independência e insubordinação em relação a esta (idem, p. 63). O episódio da Guerra dos Emboabas significaria mais um passo nessa tradição de rebeldia em relação ao domínio patrimonial português. O estabelecimento deste na região das minas à custa da hegemonia paulista apenas reforçou o padrão de autonomia local. Os paulistas "foram isolados do resto do país, e por isto não desenvolveram em seu próprio estado uma estrutura política de dependência em relação à administração central". Este argumento é central para a tese de Schwartzman, de resto continuada e aprofundada no seu livro seguinte $A s$ bases do autoritarismo brasileiro, de que foi a marginalização política do Estado de São Paulo que impediu um sistema político de representação de tipo anglo-saxão no Brasil (idem, p. 145).

A especialidade do Estado de São Paulo no argumento de Schwartzman parece-me, no entanto, fictícia. Se é verdade que, especialmente com a maciça importação de mão-deobra européia a partir da segunda metade do século XIX em todo o Brasil meridional, temos um padrão social significativamente diferente do que imperava no Brasil escravocrata, a especialidade paulista é um recurso da fantasia. Acontece com Schwartzman aquilo que Vianna Moog, tratando especificamente do bandeirante, chamava de "simbolização", ou seja, a atribuição de características irreais a dada figura como um efeito do desejo, sem vínculo com a realidade social ou histórica.

Para Moog, se há um estado cujos triunfos são produtos do colono imigrante é São Paulo. Apesar de tudo, diz ele:
[...] a julgar pela atoarda da literatura nacional em torno dos bandeirantes, dir-se-ia que o São Paulo moderno, o São Paulo das indústrias, o São Paulo do café, o São Paulo que constrói e monta o mais soberbo parque industrial da América do Sul, é obra exclusiva do bandeirante e do espírito da bandeira. Porque nisto de emprestar ao bandeirante atributo que ele nunca teve, o paulista de quatrocentos anos é um perfeito ianque. Se, para valorizar o símbolo que lhe é caro, for preciso atribuir ao bandeirante atributos orgânicos, ele o atribuirá; se para magnificá-lo for preciso torcer a história ele a torcerá. Embora tomando de empréstimo ao pioneiro, para dar ao bandeirante qualidades, intenções e preocupações que ele nunca teve, ainda é a imagem idealizada do bandeirante a que paradoxalmente mais cultua o estado mais pioneiro do Brasil. (Moog, s/d., p. 227)

É sobejamente conhecido que Simon Schwartzman não é nenhum paulista quatrocentão, mas sim um dos mais talentosos representantes de uma geração importante de pensadores sociais mineiros. O que o leva a utilizar a imagem simbolizada do bandeirante paulista é a tentativa de materializar seu desejode transformação social para o Brasil em um suporte social concreto. Se, ao contrário dos EUA, o tradicionalismo patrimonialista logrou ser dominante no Brasil, nós teríamos, no entanto, todas as condições de reverter este quadro histórico na medida em que aqui mesmo, em São Paulo mais precisamente, temos uma espécie de Nova Inglaterra tropical, a qual, se passar de elemento político dominado a dominante, pode nos dar um desenvolvimento político e econômico alternativo: livre iniciativa na economia e um sistema político baseado na representação, como no modelo anglo-saxão.

Gostaria de iniciar minha apreciação crítica procurando desenvolver até os seus limites lógicos uma perspectiva que serviu de estímulo ao trabalho do próprio Schwartzman. Como vimos, o conceito de patrimonialismo fascinava o autor pela possibilidade de, a partir dele, desafiar uma certa tradição sociológica que supunha uma dada seqüência de etapas históricas para o desenvolvimento capitalista. Ao invés de pleitear-se condições feudais ou de qualquer modo comparáveis ao processo histórico europeu, ou ainda de 
lançar mão de situações tradicionais ou primitivas indiferenciadas e gerais, o conceito de patrimonialismo serviria para especificar, determinar, particularizar um processo histórico em si peculiar. De resto, este é precisamente o desiderato do conhecimento das ciências humanas para Max Weber: o conhecimento do particular, explicar o ser desta forma dos fenômenos. E Schwartzman contribui, assim como os outros autores discutidos, com muito talento para esta determinação particular.

No entanto, se Schwartzman reconstrói a noção de processo bistórico exemplar, ele deixa intocada a noção fundamental de resultado histórico exemplar. Em outras palavras, o autor logra construir uma lógica de desenvolvimento do nosso atraso, deixando a própria noção de atraso intocada. O que é atraso permanece indeterminado, vago, implícito, como se fosse algo óbvio e indiscutivel. Não creio que este estado de coisas seja privilégio do nosso pensamento social inspirado por Max Weber. Ele é, provavelmente, típico para a maior parte do nosso pensamento social. $10 \mathrm{O}$ dado relevante da referência a Weber é que o caráter multifacetado, tensional e ambíguo da obra deste autor nos permite vislumbrar caminhos alternativos para a tematização do próprio pólo atrasado/moderno.

De início, é o próprio Weber quem aparentemente se incumbe de absolutizar, tornar indiscutível, óbvio, a medida do que é moderno e do que é atrasado. Para Weber, o protestantismo ascético atualiza e radicaliza uma forma de consciência que já existia em semente desde a concepção de mundo helênica, na sua dimensão cognitiva, e no contexto do judaísmo antigo, na sua dimensão moral. Esta atualização refere-se ao princípio do controle racional do mundo à medida que este é desencantado.

A ética protestante e o espírito do capitalismo reflete precisamente o esforço de perceber a gênese desta revolução de consciência que equivaleria à maior transformação da história humana. A leitura que percebe a ética protestante interferindo apenas na ética do trabalho, ou seja, com efeitos apenas na esfera econômica da sociedade, não percebe a dimensão do livro. Trata-se aqui de uma "recriação" do mundo, no sentido mais forte, mais amplo e mais profundo deste termo: produz-se um novo racionalismo. Racionalismo cultural, para Weber, significa que todas as esferas da sociedade, assim como todas as ações individuais no contexto dessas, vão obedecer a um novo e ubíquo quadro de referência.

No caso do racionalismo ocidental, este quadro de referência é o princípio da dominação do mundo. Isto implica que todas as dimensões do pensamento e da ação humanas, ou seja, nos seus aspectos subjetivo, social e objetvo, vão obedecer ao critério da instrumentalidade. Nesse sentido, a ética protestante favorece não apenas um "espírito do capitalismo" mas, de uma forma mais abrangente, um "espírito da reificação" (Schluchter, 1979, p. 229).

Causas da reificação vê Weber, antes de tudo, na não fraternidade essencial do caminho da salvação do protestantismo ascético e na suspeita de divinização das criaturas em toda doação de valor para as relações humanas, levando ao que se poderia chamar de "dominação da impessoalidade". As relações intersubjetivas perdem, crescentemente, a sua característica emocional, e com isto a própria peculiaridade das relações entre homens.

[...] qualquer relação puramente emocional — isto é, não motivada racionalmente - baseada em uma relação pessoal de um homem com outro facilmente cai, na ética puritana assim como em qualquer outra ética ascética, na suspeita de idolatria da carne. Em adição ao que foi dito, isto é mostrado bastante claramente no caso da amizade pela seguinte advertência: "It is an irrational act and not fit for a rational creature to love any one farther than reason will allow us [...] It very often taketh up men's minds so as hinder their love to God". Encontramos repetidas vezes tais argumentos. (Weber, 1947, pp. 98-99)

A reificação e a conseqüente atitude instrumental em relação a si e aos outros e à natureza são resultados da subordinação de todos os valores ao serviço a Deus. O decisivo, aqui, é que a reificação irá preencher as condições para o aparecimento não só de uma nova concepção "desencantada" do mundo, mas também de uma nova 
forma correspondente de consciência, na medida em que favorece o isolamento individual e a necessidade do reconhecimento, por qualquer ação com pretensão de sucesso, das leis que regem o mundo. A concepção de mundo teocêntrica e dualista é desvalorizada pela absolutização do ponto de partida do racionalismo da dominação do mundo motivado religiosamente, o que expressa o caráter autodestrutivo da ética protestante. $\mathrm{O}$ mesmo mundo que foi "encantado" através do simbolismo vem a ser, por força da necessidade do reconhecimento das leis específicas que o regem, desencantado.

Acredito que reencontramos aqui o princípio explicitado do nosso atraso. No mundo da política, por exemplo, o patrimonialismo simboliza o universo da política onde se obedecem "ainda" aos homens e não aos princípios impessoais compatíveis com o princípio da reificação do mundo. Nas notas de rodapé da Ética protestante Weber lembra que é a extraordinária distância protestante (e judaica antiga) entre os homens e a divindade que possibilita a "afinidade eletiva" entre a obediência a um Deus tão distante e a noção moderna de obediência a uma norma abstrata.

A recuperação da dimensão do próprio quadro categorial, no qual percebemos a que se referem nossas noções quase naturalizadas de atrasado e moderno, tem várias vantagens. A maior delas é que, a partir disto $e$ apenas a partir disto, é possível determinar em relação a que precisamente somos atrasados. Isto implica tornar possível uma relativização deste atraso. Não no sentido de negá-lo ou mascará-lo, mas no sentido muito preciso de torná-lo operacional, determinado, relacionado. O contrário disto seria, o que acredito ser o caso dos textos que analisamos, assumi-lo como geral, implícito, indeterminado e, como resultado final, absoluto.

Um princípio absoluto, em se tratando de comparações culturais, não serve à ciência, mas à ideologia. A ciência, e entre as ciências humanas especialmente a Sociologia, faz avaliações comparativas entre culturas, e é bom que as faça. É necessário, no entanto, saber o que se compara. À nossa indeterminação neste ponto equivale a mesma indeterminação da Sociologia americana neste particular. Sem dúvida são os EUA a primeira nação calvinista do mundo, como nos lembra Vianna Moog. É claro, por todas as injunçõesde prestígio e poder que ligam a ciência às outras esferas da sociedade, que grande parte do enorme prestígio de Max Weber naquele país tem vínculos com o seu diagnóstico específico do mundo moderno. Não é casual que o maior pensador social americano deste século, Talcott Parsons, tenha sido não só um dos mais influentes intérpretes de Weber, como tenha sido, ele próprio, influenciado fortemente por este último.

Tanto a sociologia parsoniana quanto a sociologia da modernização que tem em Parsons uma das principais referências teóricas hipostasiaram o diagnóstico histórico weberiano acerca do racionalismo ocidental, em um sistema categorial válido para quaisquer relações entre tradição e modernidade. A influência desta vertente sociológica sobre o nosso pensamento social mais recente foi e é avassaladora. Esta influência, em última análise, "explica" a naturalização dessas oposições absolutas entre atrasado e moderno como um dado óbvio e indiscutível. 11

Esta oposição entre um absolutamente atrasado e um absolutamente moderno é operante não apenas para análises institucionais mas também para as assim chamadas teorias de cultura política. Assim, o conceito, central nessas análises, de "confiança intersubjetiva" como índice da presença ou ausência de uma cultura política cívica e participativa pode ser visto de um modo bem mais ambivalente do que é normalmente apresentado nestes estudos.

Também esta noção pode ser vista como um subproduto do diagnóstico weberiano do racionalismo ocidental. Afinal, o que é denominado aqui, com um tom unilateralmente positivo, como confiança intersubjetiva é a capacidade protestante sectária de associação para fins de interesse comum. Sem dúvida, é precisamente esta qualidade que permite a associação de pessoas para além da comunidade familiar, na medida, precisamente, em que não se confunde relação afetiva com relação de interesses. Novamente temos a aplicação do princípio de que se deve 
deixar de obedecer aos homens para obedecer a Deus (a norma moral abstrata). É este aspecto fundamental que possibilita relações "horizontais" de interesses, ou seja, relações entre iguais (pessoas da mesma classe social, mesma profissão etc.), ao invés das relações verticais entre pessoas não iguais segundo o próprio modelo hierarquizado da comunidade familiar. De forma muito significativa, este é o ponto central das teorias sobre cultura política desde o clássico de Almond e Verba, passando por Banfield, até os trabalhos mais contemporâneos de um Ronald Inglehart (1990, pp. 23-25). Com sinal trocado, este tema também é central no nosso pensamento social, ou seja, nossa relativa ou absoluta incapacidade democrática é percebida como decorrendo da ausência desta capacidade. Reencontramos aqui desde as incapacidades do homem cordial de Sérgio Buarque até a ausência de associativismo e iniciativa do Brasil tradicional de Schwartzman.

Vale a pena acompanharmos a gênese histórica da "confiança intersubjetiva". Talvez isso possa permitir que deixemos de percebê-la como a imagem do bem absoluto e passemos a ver sua qualidade cultural ambígua, implicando perdas e ganhos como toda e qualquer escolha humana, seja ela individual ou cultural. Para Max Weber, a confiança intersubjetiva é produto do espírito da seita, por oposição ao espírito da Igreja católica. Este ponto é o tema do seu "Die Protestantischen Sekten und der Geist des Kapitalismus" ("As seitas protestantes e o espírito do capitalismo"), onde o autor procura fazer uma "etnografia" do espírito sectário, precisamente nos Estados Unidos do começo deste século.

Nesse sentido, ele examina a enorme influência da religiosidade nos EUA, característica essa aparentemente surpreendente num país que foi um dos pioneiros ardorosos da separação entre a Igreja e o Estado. A surpresa se dissipa à medida que percebemos a necessidade econômica e social fundamental da afiliação religiosa naquele país. $\mathrm{O}$ não pertencimento a uma seita significava ruína econômica, perda de crédito e de clientela. Era o pertencimento à seita que produzia a "confiança intersubjetiva" enquanto precondição para a aceitação no mercado. Longe de interpretar a maciça afiliação religiosa americana (cerca de 94\% na época) como uma hipocrisia destinada a produzir resultados utilitários, Weber percebe a especificidade daquele país precisamente a partir deste fato único.

É que sendo o país do protestantismo sectário por excelência, os EUA apresentam, no grau mais puro, as qualidades distintivas do espírito da seita. Ao contrário da Igreja, onde o pertencimento é presumido desde o nascimento (o batismo infantil é o melhor exemplo disto), as seitas pressupõem a associação voluntária do membro adulto, a partir de qualificações éticas adquiríveis individualmente. Weber (1947, p. 217) já fazia menção à secularização deste princípio nos EUA do começo deste século, sendo a filiação religiosa acrescida ou substituída pela filiação às mais diversas associações, sociedades, clubes e universidades. O princípio voluntário exigia também severo controle grupal da comunidade local sobre seus associados, única instância capaz de admitir e atestar a qualificação dos filiados. Temos aqui já uma interessante influência religiosa do princípio localista e comunitário americano. A coesão destas comunidades era tão forte que este parece ter sido um dos motivos para o povoamento citadino, por oposição à colonização rural, da Nova Inglaterra americana.

Como já era de se esperar, Weber interpreta este estado de coisas de maneira abertamente positiva. As seitas ajudam a produzir o indivíduo moderno, em flagrante oposição aos contextos de obediência pessoal da autoridade patriarcal. Elas ajudam a criar "aqueles homens que obedecem antes a Deus que a outros homens" (Weber, 1947, p. 235). Para Weber, esta seria, inclusive, a característica específica da democracia americana enquanto tal: o fato de não ser apenas um monte disforme de indivíduos, mas uma reunião voluntária, ainda que severamente exclusiva, de indivíduos associados (idem, p. 215).

A ambigüidade do princípio associativo, tão caro ao próprio Weber, já vem nomeada no "ainda que severamente exclusiva", posto, de forma muito sintomática, entre vírgulas, a título de restrição. Temos aqui, também, uma continuidade com o judaísmo que é a dupla moral: 
uma interna, válida para os irmãos de fé, e outra externa, para os não-crentes. É evidente que esta qualidade não se mantém apenas no nível do comércio econômico, mas se expande para todas as esferas da vida, inclusive a esfera política.

Esta interessante distinção weberiana entre seita e Igreja foi apropriada e radicalizada por Ernst Troeltsch (1994) como dois princípios fundamentais de organização social. Também Robert Bellah et al. (1985) perceberam a riqueza desta distinção categorial não apenas para a esfera religiosa, mas para a sociedade como um todo. Afinal, o que está em jogo são formas radicalmente opostas de ver-se a si e aos outros, o que implica falar, portanto, deformas alternativas de solidariedade social em sentido amplo.

Para Bellah, a Igreja pode ser caracterizada como uma concepção orgânica de instituição religiosa e social, possibilitando a percepção da presença viva de Cristo na Terra. É deste poder que derivam todos os sacramentos. Fundamental para nossa discussão é o fato de que a Igreja é vista como possuindo prioridade ontológica e temporal sobre os indivíduos. Mediante a palavra sagrada e os sacramentos a Igreja aceita e recebe todos os indivíduos tal como eles são, estabelecendo uma hierarquia entre eles a partir do grau de espiritualidade e virtuosismo que é possível a cada qual em termos de vida cristã. O conceito de Igreja envolve, para uma teoria social e política, as noções complementares de hierarquia e elitismo.

A seita, ao contrário, enfatiza, como vimos, o elemento de associação voluntária de fiéis. Neste sentido, o indivíduo tem certa prioridade, temporal ao menos, sobre a comunidade religiosa. A enorme ênfase sectária no voluntarismo e igualdade entre todos os crentes torna-a afim do igualitarismo democrático e das formas associativistas baseadas na autonomia individual. Como Max Weber, Robert Bellah et al. (1985, pp. 243-248) consideram o sectarismo a maior fonte do individualismo americano e da idéia peculiarmente americana (pervasive american) de que os grupos sociais são frágeis e precisam de constante energia para se manterem funcionando.
Mais interessante para nós, no entanto, é a ambigüidade do princípio democrático da seita. A ênfase na pureza, responsável em última instância pela enorme energia sectária em perseguir seus fins associativos, acarreta, simultaneamente, uma intransponível oposição entre sectários tidos como puros e não-sectários tidos como impuros. A diferença com relação ao princípio da Igreja não é a posição paradigmática do conceito de pureza. O princípio da pureza é básico tanto na Igreja quanto na seita. O princípio hierárquico da Igreja, no entanto, permiteaceitar o impuro, ao passo que a seita o rejeita. Daí o interesse das ambigüidades culturais para o estudo de questões universais, daí a afinidade eletiva "democrática" do valor básico do liberalismo político — a tolerância com o princípio hierárquico da Igreja, que a todos acolhe e garante um lugar, e não com o princípio exclusivo da seita. A seita, ao traçar uma linha divisória intransponível entre o santo e o réprobo, retira a possibilidade de qualquer comércio entre os dois. A ênfase aqui é na intolerância com 0 outro, seja este o negro, o latino etc. Com a secularização deste princípio, este outro pode ser qualquer um que seja diferente e não apenas o infiel.

O atual debate acerca do multiculturalismo nos EUA nos dá uma idéia interessante do estado de coisas contemporâneo neste contexto. Como se sabe, o debate sobre o multiculturalismo ocorre num contexto de renovação de temas políticos, especialmente no campo da esquerda. Assim, se antes a preocupação dominante referiase, quase que exclusivamente, ao tema da redistribuição de riquezas, vê-se agora um interesse crescente pelo tema do reconhecimento das diferenças. $\mathrm{O}$ fato interessante neste debate, para nossos propósitos, não é apenas o enriquecimento da agenda política e intelectual com novos desafios antes insuspeitos. O fato mais interessante para nós é que o desafio teórico e prático americano se dá no campo da aceitação do diferente, no sentido mais amplo deste termo, que havíamos apontado acima.

Não se deve menosprezar a importância deste debate. Ele inaugura uma complexidade inaudita para o debate político teórico e prático deste final de século. $\mathrm{O}$ que vem sendo chamado de política do reconhecimento obedece a uma 
lógica substancialmente distinta do paradigma redistributivo anterior. Como observa apropriadamente Nancy Fraser (1997, p. 15), a necessidade de redistribuição é uma injustiça econômica que pede alguma forma de reestruturação socioeconômica, ao passo que a necessidade de reconhecimento pede uma mudança cultural ou simbólica. Apesar dos dois quase sempre aparecerem juntos na realidade empírica, é necessário separá-los analiticamente.

Como diz Charles Taylor (1994) no seu The politics of recognition, a nossa identidade é formada pelo reconhecimento ou pela ausência deste. Deste modo, uma pessoa pode sofrer uma distorção real se a sociedade em volta dela refletir uma imagem de si desfavorável. Neste sentido, não reconhecimento não é algo inofensivo e sem conseqüências; pode ser uma forma de opressão insidiosa, aprisionando uma pessoa em uma concepção falsa, distorcida e reduzida de si. Assim, reconhecimento não é uma cortesia ou gentileza, mas uma necessidade vital. Uma imagem depreciativa de povos ou comunidades pode tornar-se uma das formas mais potentes e expressivas da opressão destes. Livrar-se de uma identidade depreciativa torna-se fundamental, seja para a vida privada, seja para a vida coletiva.

Reconhecimento, nas modernas sociedades democráticas, implica reconhecimento entre iguais, implica dignidade, no vocabulário de Taylor, por oposição a honra, na qual é essencial que apenas alguns a possuam. Por outro lado, esta passagem da honra à dignidade, segundo Taylor (1994, pp. 27-30), acarreta também uma mudança naforma de percep̧̧ão da moralidade. Esta passa a ser vista em conexão com a autenticidade, ou seja, com uma voz interna que emana da natureza subjetiva de cada um. Existe, neste sentido, uma certa forma de ser gente que é o modo especifico de cada pessoa. O desafio moderno é articular universalidade e diferença, portanto.

O que torna a questão especialmente difícil é que este princípio da cidadania igualitária universalmente aceito pode entrar em contradição com o princípio da autenticidade, o qual é, antes de tudo, um ideal doreconbecimento da diferença. Sem dúvida existe margem para uma defesa universalista deste último também, na medida em que cada qual tem o direito de ser reconhecido na unicidade da sua identidade, ou seja, na especificidade da sua diferença. A prática é que os grupos e pessoas que se sentem discriminados percebem precisamente o seu direito à diferença ignorado e assimilado a alguma outra forma dominante de identidade social, acarretando, desse modo, a existência de diferenças dominantes e oprimidas.

Embora este tipo de problema seja comum a todas as sociedades modernas, ele torna-se um problema especialmente delicado em tipos de sociedades como a americana, baseadas no princípio sectário de organização social. O déficit típico de uma sociedade deste tipo não é o associativismo ou a consideração racional de interesses de longo prazo, mas os efeitos do que Weber chamava de uma ética da não fraternidade, típica do ascetismo protestante. Daí o déficit nas questões de reconhecimento, na dimensão simbólica do reconhecimento do outro, portanto, e não propriamente na dimensão socioeconômica da redistribuição. Daí, talvez, também a perplexidade acerca do insucesso de certas políticas redistributivas a minorias raciais, por exemplo. $\underline{12}$ Procura-se "compensar" um déficit simbólico com a moeda econômica, quando os problemas possuem dimensões distintas.

Este dilema é tão profundo que o próprio Taylor, um dos principais críticos do individualismo e do liberalismo radical, fundamenta a sua defesa de grupos dominados e oprimidos pelo não reconhecimento de sua especificidade cultural, a partir de um transporte do modelo de direitos individuais para os direitos grupais. Talvez o universo simbólico referido pela noção de reconhecimento esteja, pelo menos parcialmente, aquém e além do alcance da eficácia legal. Talvez este universo se refira a valores ainda mais básicos da convivência social, misturando aspectos emotivos e motivacionais com aspectos racionais e conscientes da solidariedade social.

Não pretendo utilizar o Brasil como um contra-exemplo. Seria apressado e talvez perigoso fazê-lo. Estes são desafios comuns a qualquer sociedade moderna. Talvez as ênfases e 
as proporções entre os diversos déficits socioeconômicos e culturais variem. Existe uma grande probabilidade que assim o seja. Pesquisas posteriores podem, talvez, trazer maior clareza neste campo. O meu intuito neste texto foi apenas chamar a atenção para a importância de rejeitarmos modelos societários exemplares e absolutos. As escolhas culturais, assim como as individuais, implicam perdas e ganhos. Perceber aonde temos a aprender com outros povos e sociedades é uma reflexão que deve ser simultânea àquilo que devemos rejeitar como impróprio. $\mathrm{O}$ primeiro passo para este desiderato parece-me ser a tentativa de qualificarmos nosso atraso, torná-lo relativo, determinado. Antes do que tentar soluções e sínteses apressadas, precisamos perceber que vale a pena nos propor a pergunta.

\section{NOTAS}

1 Este texto foi publicado em português, sob o título "Rejeições religiosas do mundo e suas direções", nacoletânea Ensaios de Sociologia (Weber, 1979).

2 Dois aspectos parecem-me decisivos na análise das influências diferenciais da ética religiosa sobre a condução da vida prática. Por um lado, temos um elemento imanente à mensagem religiosa, nomeadamente, a concepção da divindade. A investigação comparativa descobre um Deus pessoal e transcendente no Ocidente e um Deus imanente e impessoal no Oriente. Essa distinção, entretanto, ganha toda a sua força apenas se vinculada com o conteúdo da promessa religiosa e do caminho da salvação. Por outro lado, um elemento extra-religioso assume importância central, nomeadamente, os portadores sociais da ética religiosa. Aqui importa saber que interesses ideais e materiais do estrato social em questão determinam a ética religiosa. Todos esses aspectos condicionam-se mutuamente. Importa muito, por exemplo, se o estrato social portador da promessa e do caminho da salvação religiosa privilegia uma interpretação intelectual (como no Oriente) ou prática (como no Ocidente) dos mesmos. Ver Weber (1947, pp. 536-573).
3 Weber fala mais precisamente de caminho para a certeza da salvação. Cf. Weber (1979, p. 110).

4 É interessante notar que, mais tarde, Schluchter torna-se bem mais reticente e cuidadoso em relação a este aspecto. Cf. Schluchter (1988, pp. 98-101).

5 Paulo Luiz Lavigne Esteves (1998, p. 100), em um texto de resto muito estimulante, associa, indevidamente, esta civilidade ritual "oriental", que remete aos bons costumes, à civilidade moderna "ocidental", a qual remete, na verdade, a uma internalização do dilema ético.

6 Quando me refiro aqui a protestante ascético, penso em modelos de personalidade e instituições que, embora secularizados, foram inspirados e obedeceram escolhas valorativas que remontam ao protestantismo ascético.

7 Uso este termo sem nenhuma intenção pejorativa. Muito pelo contrário. Em certo sentido, toda ciência humana é, ou deveria ser, culturalista.

8 Este era também um tema dileto de Simmel, especialmente no seu livro sobre a filosofia do dinheiro. Em português, ver coletânea com um texto homônimo (Souza e Oelze, orgs., 1998).

9 Para Moog, o colono do sul do país é o nosso correlato mais próximo do pioneiro.

10 Mesmo para um antropólogo tão sensível às especificidades culturais como Roberto Da Matta, o princípio da hierarquia é percebido como unilateralmente negativo, ao contrário do que pensa seu mestre Louis Dumont. Cf. Da Matta (1978, pp. 139-193).

11 O próprio Schwartzman (1975, p. 143), recorrendo a textos de Stein Rokkan e S.M. Lipset, faz uma exposição interessante deste instrumental teórico aplicado à análise política.

12 Ver, sobre isto, a coletânea com textos comparativos Multiculturalismo e racismo: uma comparação Brasil e Estados Unidos (Souza, org., 1997). 


\section{BIBLIOGRAFIA}

BELLAH, Robert. (1973), "Religiöse evolution", in Constans Seyfarth e Walter Sprondel (orgs.), Seminar: religion und gesellschaftliche Entwicklung, Frankfurt, Suhrkamp.

BELLAH, Robert et al. (1985), Habits of the heart: individualism and commitment in American life. Nova York, Harper and Row.

BUARQUE DE HOLANDA, Sérgio. (1963), Raízes do Brasil. Brasília, Ed. da UnB. (1978),Cobra de vidro. São Paulo, Perspectiva.

DA MATTA, Roberto. (1978), Carnavais, malandros e heróis. Rio de Janeiro, Zahar.

ESTEVES, Paulo Luiz Moreaux Lavigne. (1998), "Cordialidade e familismo amoral: os dilemas da modernização".Revista Brasileira de Ciências Sociais,Anpocs, 36: 95-107.

FAORO, Raimundo. (1984), Os donos do poder. Rio de Janeiro, Globo.

FRASER, Nancy. (1997), Justice interruptus. Nova York, Routledge.

HABERMAS, Jürgen. (1987), Die Theorie des kommunikativen Handelns. Frankfurt, Suhrkamp.

INGLEHART, Ronald. (1990), Cultural shift. Princeton, Princeton Press.

MOOG, Vianna. (s/d.), Bandeirantes e pioneiros. Lisboa, Livros do Brasil.

ROTH, Günther. (1995), "Weber the would be Englishman: anglophilia and family history", in Hartmut Lehman e Günther Roth (orgs.), Weber's protestant ethics: origins, evidence, contexts, Cambridge, Cambridge Press.
SCHLUCHTER, Wolfgang. (1979), Die Entwicklung des Okzidentalen Rationalismus. Tübingen, J.C.B.Mohr. (1980), Rationalismus der Weltbeherrschung.

Frankfurt, Suhrkamp. (1988), Religion und Lebensfübrung. Frankfurt, Suhrkamp.

SCHWARTZMAN, Simon. (1975), São Paulo e o Estado nacional. São Paulo, Difel.

SOUZA, Jessé (org.). (1997), Multiculturalismo e racismo: uma comparação Brasil e Estados Unidos. Brasília, Paralelo 15.

SOUZA, Jessé e OELZE, Berthold (orgs.). (1998), Simmel e a modernidade. Brasília, Ed. da UnB.

TAYLOR, Charles. (1994), "The politics of recognition", in Amy Gutman (org.), Multiculturalism, Princeton, Princeton Press.

TROELTSCH, Ernst. (1994), Die Soziallehren der Christlichen Kirchen und Gruppen. Tübingen, J.C.B. Mohr.

WEBER, Max. (1947), Gesammelte Schriften zur Religionssoziologie. Vol. 1. Tübingen, J.C.B. Mohr.

(1958), Gesammelte Politische Schriften.

Tübingen, J.C.B. Mohr. (1979), Ensaios de Sociologia. Rio de Janeiro, Zahar.

(1985), Witschaft und Gesellschaft. Tübingen, J.C.B. Mohr.

WERNECK VIANNA, Luiz. (no prelo), "Weber e a interpretação do Brasil", in Jessé Souza (org.), O malandro e o protestante: a tese weberiana e a singularidade cultural brasileira, Brasília, Ed. da UnB. 